\title{
An Empirical Study of Servqual as a Tool for Service Quality Measurement
}

\author{
Sabrina Tazreen \\ Lecturer. (Marketing) \\ Faculty of Business Administration, University of Science and Technology Chittagong.
}

\begin{abstract}
To survive and excel in today's competitive market organizations must realize the significance of customer-oriented business philosophies and quality management approaches in managing the business. Customers are becoming more aware of their requirements. Their expectations and perceptions are continually evolving making it more difficult for the service providers to measure and manage services effectively and efficiently.

Implementation of total quality in the service industry is comparatively more complex and difficult due to the fact that quality of services cannot be defined objectively. Additionally, service industry by nature has less control over factors which affect quality. Very few methods are considered to be effective measurement tools for services so far while a number of methods have been introduced and practiced for measuring the quality of physical goods. This paper attempts to highlight the implication of SERVQUAL, one of the widely accepted methods for measuring service quality. The SERVQUAL methodology is briefly demonstrated by a small survey conducted on a randomly selected bunch of customers regarding the service quality provided by a particular commercial bank. The paper concludes with some recommendations regarding further research topics related to service quality measurement.
\end{abstract}

\section{Introduction:}

A woman walked up to the branch manager of a bank. "Are you hiring any help?" she asked.

"No," he said. "We already have all the staff we need."

"In that case, would you mind trying to find someone to help me in the safe deposit area?" she asked.

This story is just a comical representation of a customer's dissatisfactory reaction resulted from a service failure of a bank. The term Customer Satisfaction has become the prime concern of most of the organizations to be competitive in the industry. Determining and meeting customer expectation regarding services is the key to make satisfied customers and the best way for determining customers' needs and expectation is the use of surveys and researches- the key vehicle for understanding customer expectations and perceptions of services.

This paper attempts to focus the implication of SERVQUAL scale for measuring service quality in terms of the differences between the customer expectations and their perceptions regarding the service consumed.

Measuring service quality had always been a challenge for service providers because of the intangible and most notably the inseparable and heterogeneous nature of service. As such services are more akin to performances rather than objects. These distinctions enabled Parasuranam, Zeithmal \& Berry (1985) to develop an instrument for measuring Service quality, SERVQUAL, which has subsequently dominated both academic and practitioner perspectives (Buttle, 1996; Robinson,1999). SERVQUAL measures perceptions of service quality across five dimensions: tangibles; reliability; responsiveness; assurance and empathy.

SERVQUAL (an acronym derived from the term 'Service Quality') is a well tested survey method for measuring service quality which focuses on five service quality dimensions. SERVQUAL surveys usually include 22 service areas distributed throughout the five service quality dimensions. The survey often asks the customers to provide two different ratings on each attribute- one reflecting the level of service they would expect from excellent companies in a given sector and the other reflecting their perception of the service delivered by a specific company within a sector. The difference between the expectation and perception rating constitutes a qualified measure of service quality.

Service industries cover a wide range of differentiated organizations such as health care, education, banking, insurance, hotels, transport, restaurant, etc. Such systems involve a very large variety of business processes and a large scale interaction with variety of customers. SERVQUAL method is more or less suitable for most of the service sectors. Still, the scope of SERVQUAL survey is limited to some particular sectors. The use of SERVQUAL seems to be most effective in financial services, health care and education sector. This 
paper attempts to demonstrate the methodology of SERVQUAL by a survey conducted on the customers of a local commercial bank regarding the retailing banking services provided by the bank. The bank has been termed as Bank X (hypothetical name). The sample size includes only forty customers because of the time and cost constraints. The questionnaire was made shorter by selecting 16 questions from among the 22 structured questions. In fact the survey only exhibits the implication and methodology of SERVQUAL in a service industry.

\section{Defining Service and Service Quality Measurement:}

Thus, Service quality is a concept that has aroused considerable interest and debate in the research literature because of the difficulties in both defining it and measuring it with no overall consensus emerging on either (Wisniewski, 2001). There are a number of different "definitions" as to what is meant by service quality. One that is commonly used defines service quality as the extent to which a service meets customers' needs or expectations (Lewis and Mitchell, 1990; Dotchin and Oakland, 1994a; Asubonteng et al., 1996; Wisniewski and Donnelly, 1996). Service quality can thus be defined as the difference between customer expectations of service and perceived service. If expectations are greater than performance, then perceived quality is less than satisfactory and hence customer dissatisfaction occurs (Parasuraman et al., 1985; Lewis and Mitchell, 1990).

However the study of service quality did not come into its own as an area of marketing importance until research in the early 1980s established that attitude was a significant part of service quality. The earliest concern for what has become to be known as service quality appeared in 1976. Anderson, et al (1976) recognized importance of selection as a priority for obtaining and retaining customers.

Churchill and Suprenant (1982) were among the earliest to hold the view later shared by others that service quality was an attitude. They were the first researchers to see the significance of attitude as a principal factor leading to superior service quality. One year after this significant research, Lewis and Booms (1983) concluded that satisfaction was similar to attitude, and consequently they noted the significance of processes and outcomes in defining service quality.

A number of scholars have conducted services quality researches and opined in different ways about service quality. Some of those are Holbrook and Corfman, Maynes, Zeithaml, Cronin, Jr. and Taylor, Dabholkar, Bitner and others.

In an attempt to address the issue of how to measure service quality, a scale based upon the utilization of ten elements was developed by Parasuraman, et al based upon a series of focus group interviews, which could be used to measure service quality perceptions. Originally, the ten elements developed for use in measuring service quality were tangibles, reliability, responsiveness, competence, courtesy, credibility, security, access, communications, and understanding the customer. Further studies by Parasuraman, et al (1988) brought about a major modification that changed the dimensions that could be used to measure service quality perceptions. Three of the original ten elements - tangibles, reliability, and responsiveness - remained unchanged. The other seven original elements were combined into two elements. Those elements known as competence, courtesy, credibility, and security were combined to form one of the new elements known as assurance, and the elements of access, communications, and understanding the customer were combined to form the new element known as empathy.

Now, the five elements that made up what the authors called SERVQUAL were the following five dimensions of service quality: tangibles, reliability, responsiveness, assurance, and empathy. The factors covered by the dimensions are given in the following table:

\begin{tabular}{|c|c|}
\hline Dimensions & Factors \\
\hline Tangibles & Physical facilities, equipment and appearance of personnel. \\
\hline Reliability & $\begin{array}{l}\text { Ability to perform the promised service dependably and } \\
\text { accurately. }\end{array}$ \\
\hline Responsiveness & Willingness to help customers and provide prompt service. \\
\hline Assurance & $\begin{array}{l}\text { Knowledge and courtesy of employees and their ability to } \\
\text { inspire trust and confidence. }\end{array}$ \\
\hline Empathy & $\begin{array}{l}\text { Caring and individualized attention that the firm provides } \\
\text { to its customers. }\end{array}$ \\
\hline
\end{tabular}

Table: 1: Dimensions of Service Quality 
-Tangibles: Tangibles would include those attributes pertaining to physical items such as equipment, buildings, and the appearance of both personnel and the devices utilized to communicate to the consumer. Bitner (1992) presented her conceptual framework for examining the impact of physical surroundings as it related to both customers and employees. Berry and Clark (1991) provided validation of the physical appearance on the consumer's assessment of quality. With the research by Bitner (1990), it was noted that physical appearance might influence the consumer's level of satisfaction. Tangible was one of the original dimensions that were not modified by Zeithaml, et al (1988).

-Reliability: Reliability relates to the personnel's ability to deliver the service in a dependable and accurate manner. Numerous researchers, including Garvin (1987) found that reliability tends to always show up in the evaluation of service. Parasuraman, et al (1988) indicated that reliability normally is the most important attribute consumers seek in the area of quality service. It was also determined by Parasuraman, et al (1991) that the conversion of negative wording to positive wording as suggested by Babakus and Boller (1991) and Carman (1990) increased the accuracy of this dimension. Negative wording in the request for a customer response caused the customer to misinterpret this particular determinant. Walker (1995) found that if there is an adequate delivery of the basic level of service, then peripheral performance leads consumers to evaluate the service encounter as satisfactory. Reliability was one of the original dimensions not modified by Zeithaml, et al (1988).

-Responsiveness: The desire and willingness to assist customers and deliver prompt service makes up the dimension of responsiveness. Parasuraman, et al (1991) include such elements in responsiveness as telling the customer the exact time frame within which services will be performed, promptness of service, willingness to be of assistance, and never too busy to respond to customer requests. Bahia and Nantel (2000) disregarded responsiveness in their research, claiming a lack of reliability even though they recognized SERVQUAL and all of its dimensions as the best known, most universally accepted scale to measure perceived service quality. Responsiveness was also one of the original dimensions not modified by Zeithaml, et al (1988).

-Assurance: Knowledgeable and courteous employees who inspire confidence and trust from their customers establish assurance. In banking studies by Anderson, et al (1976), it was determined that a substantial level of trust in the bank and its abilities was necessary to make the consumer comfortable enough to establish a banking relationship. Parasuraman, et al (1991) included actions by employees such as always courteous behavior instills confidence and knowledge as prime elements of assurance. Assurance replaces competence, courtesy, credibility, and security in the original ten dimensions for evaluating service quality (Zeithaml, et al, 1988).

-Empathy: Empathy is the caring and personalized attention the organization provides its customers. Individual attention and convenient operating hours were the two primary elements included by Parasuraman, et al (1991) in their evaluation of empathy. The degree to which the customer feels the empathy will cause the customer to either accept or reject the service encounter. Empathy replaces access, communication, and understanding the customer in the original ten dimensions for evaluating service quality (Zeithaml, et al, 1988).

\section{Methodology Of SERVQUAL Survey For Measuring The Gap Between Customer Expectation And Their Perception Regarding The Service Provided By Bank X:}

A small survey has been conducted on the customers of 'Bank X', locally serving for more than one decade to represent the way to conduct SERVQUAL survey. The instrument's design causes it to be best suited for use as a diagnostic methodology utilized for determining large areas of service quality strengths and weaknesses.

To evaluate the five service quality dimensions, sixteen statements were selected from the structured SERVQUAL questionnaire format and then modified to make it precise and best suitable for banking sector. The number of questions was squeezed because of the convenience of collecting responses from the customers who were less willing to answer so many questions.

Two sets of questionnaires were prepared including sixteen identical statements. One set of questions asks the customers to indicate the extent to which the bank's services should possess the features described by each statement. The other set asks about their views regarding the extent to which they believe Bank X has the features and benefits described by the statement.

The questionnaire representing customer expectation focuses on the word 'should' to state the level of expectation regarding each criterion. A seven point Likert scale is used to get the level of expectation and perception associated with each service quality criterion. After conducting the survey all the questionnaires were collected for tabulation and analysis. 
Target sample: Generally, the customers of Bank X are categorized into two major groups: Corporate customers and Retail customers. The retail customers have been chosen to conduct the survey as corporate clients are treated to be the most valued ones and they usually get separate concentration and best services. Moreover they are difficult to access. Thus, the retails customers are more likely to provide the most accurate response regarding the service.

Sample size: The research sample consists of $\mathbf{4 0}$ customers of different branches of Bank X

Data Analysis: For the analysis of the collected data a primary or rough analysis was conducted to validate the questionnaire for gathering the adequate information. The filled up questionnaires were scanned to discard unwanted or insincere responses. The data analysis was conducted using SPSS.

Table: 2 The 16 statements used for collecting responses:

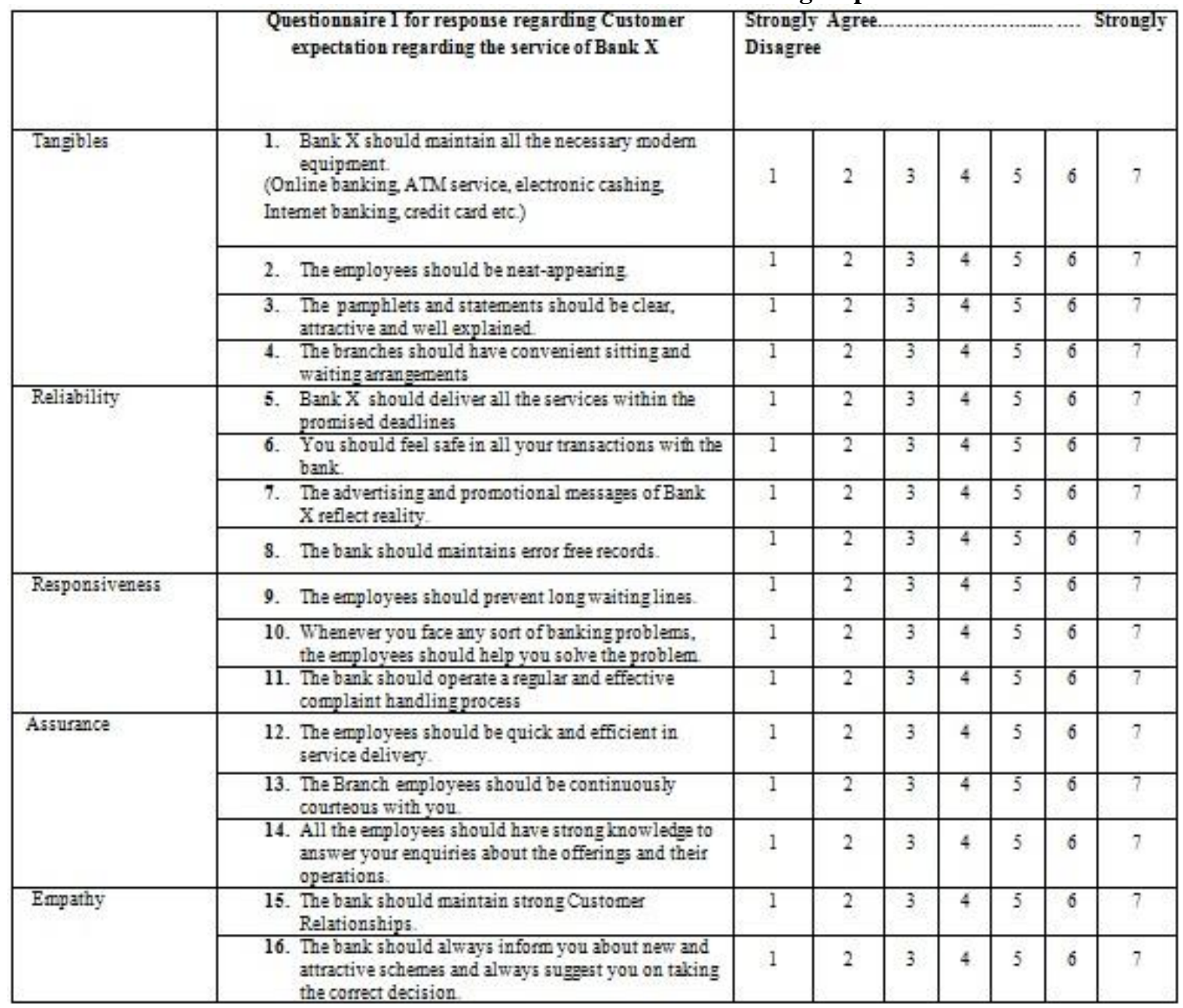


Table 3:

\begin{tabular}{|c|c|c|c|c|c|c|c|c|}
\hline & $\begin{array}{l}\text { Questionnaire } 2 \text { for response regarding Customer } \\
\text { perception regarding the service of Bank } X\end{array}$ & $\begin{array}{l}\text { Stron } \\
\text { Disa: }\end{array}$ & gre & & & & ing & \\
\hline \multirow[t]{4}{*}{ Tangibles } & $\begin{array}{l}\text { 1. Bank } X \text { has all the necessary modern equipment. } \\
\text { (Online banking, A TM. service, electronic cashing. } \\
\text { Intemet banking, credit card etc) }\end{array}$ & 1 & 2 & 3 & 4 & 5 & 6 & 7 \\
\hline & 2. The employees are neat-appearing & 1 & 2 & 3 & 4 & 5 & 6 & 7 \\
\hline & $\begin{array}{l}\text { 3. The pamphlets and statements are clear, attractive } \\
\text { and well explained. }\end{array}$ & 1 & 2 & 3 & 4 & 5 & 6 & 7 \\
\hline & $\begin{array}{l}\text { 4. The branches has convenient sitting and waiting } \\
\text { arrangements }\end{array}$ & 1 & 2 & 3 & 4 & 5 & 6 & ? \\
\hline \multirow[t]{4}{*}{ Reliability } & $\begin{array}{l}\text { 5. Bank } X \text { delivers all the services within the promised } \\
\text { deadlines }\end{array}$ & 1 & 2 & 3 & 4 & 5 & 6 & 7 \\
\hline & 6. You feel safe in all your transactions with the bank. & 1 & 2 & 3 & 4 & 5 & 6 & 7 \\
\hline & $\begin{array}{l}\text { 7. The advertising and promotional messages of Bank } \\
\mathrm{X} \text { reflect reality. }\end{array}$ & 1 & 2 & 3 & 4 & 5 & 6 & 7 \\
\hline & 8. The bank maintains error free records. & I & 2 & 3 & 4 & 5 & 6 & 7 \\
\hline \multirow[t]{3}{*}{ Responsiveness } & 9. The employees prevent long waiting lines. & 1 & 2 & 3 & 4 & 5 & 6 & ? \\
\hline & $\begin{array}{l}\text { 10. Whenever you face any sort of banking problems. } \\
\text { the employees helps you solve the problem. }\end{array}$ & 1 & 2 & 3 & 4 & 5 & 6 & 7 \\
\hline & $\begin{array}{l}\text { 11. The bank operates a regular and effective complaint } \\
\text { handling process }\end{array}$ & 1 & 2 & 3 & 4 & 5 & 6 & 7 \\
\hline \multirow[t]{3}{*}{ Assurance } & $\begin{array}{l}\text { 12. The employees are quick and efficient in service } \\
\text { delivery. }\end{array}$ & 1 & 2 & 3 & 4 & 5 & 6 & 7 \\
\hline & $\begin{array}{l}\text { 13. The Branch employees are continuously courteous } \\
\text { with you. }\end{array}$ & 1 & 2 & 3 & 4 & 5 & 6 & 7 \\
\hline & $\begin{array}{l}\text { 14. All the employees have strong knowledge to answer } \\
\text { your enquiries about the offerings and their } \\
\text { operations. }\end{array}$ & 1 & 2 & 3 & 4 & 5 & 6 & 7 \\
\hline \multirow[t]{2}{*}{ Empathy } & 15. The bank maintains strong Customer Relationships. & 1 & 2 & 3 & 4 & 5 & 6 & ? \\
\hline & $\begin{array}{l}\text { 16. The bank always informs you about new and } \\
\text { attractive schemes and always suggest you on taking } \\
\text { the correct decision. }\end{array}$ & 1 & 2 & 3 & 4 & 5 & 6 & 7 \\
\hline
\end{tabular}

To make the calculation clear let's consider any one statement from the questionnaire. The following table represents the calculation of the difference between the scores of Questionnaire 1 and 2. Statement

Table: 4

Différence $=$ Expectation $(Q$ 1) - Perception (Q 2)

Questionnaire 1(Expectation)

Strongly Agree Strongly disagree

The branch should have convenient sitting and waiting arrangements

\begin{tabular}{|l|l|l|l|l|l|l|}
\hline 1 & 2 & 3 & 4 & 5 & 6 & 7 \\
\hline
\end{tabular}

Questionnaire 2 (Perception)

The branch has convenient sitting and waiting arrangements

Difference: Expectation- perception $=1-4=-3$, thus, the gap between customer expectation and perception is -3 which represents that according to the respondent the service performance could not meet the expectation level.

The Range of gap scores: $-6,-5,-4,-3,-2,-1,0,1,2,3,4,5,6$ 
An Empirical Study of Servqual as a Tool for Service Quality Measurement

Table 5: The following table shows the average gap between customer expectation and their perception regarding various service features of Bank $X$.

\begin{tabular}{|c|c|c|}
\hline $\begin{array}{l}\text { Service Quality } \\
\text { Dimensions }\end{array}$ & $\begin{array}{c}\text { Mean } \\
\text { Difference of } \\
\text { each } \\
\text { statement }\end{array}$ & $\begin{array}{c}\text { Mean difference for each SQ } \\
\text { Dimension }\end{array}$ \\
\hline Tangibles & & \\
\hline Statement 1 & -1.2 & \multirow{4}{*}{-0.61} \\
\hline Statement 2 & 0.325 & \\
\hline Statement 3 & -0.05 & \\
\hline Statement 4 & -1.525 & \\
\hline \multicolumn{3}{|l|}{ Reliability } \\
\hline Statement 5 & -0.85 & \multirow{4}{*}{-0.775} \\
\hline Statement 6 & -0.775 & \\
\hline Statement 7 & -0.55 & \\
\hline Statement 8 & -0.925 & \\
\hline \multicolumn{3}{|l|}{ Responsiveness } \\
\hline Statement 9 & -2.125 & \multirow{3}{*}{-1.61} \\
\hline Statement 10 & -1.175 & \\
\hline Statement 11 & -1.525 & \\
\hline \multicolumn{3}{|l|}{ Assurance } \\
\hline Statement 12 & -1.1 & \multirow{3}{*}{-0.72} \\
\hline Statement 13 & -0.825 & \\
\hline Statement 14 & -0.225 & \\
\hline \multicolumn{3}{|l|}{ Empathy } \\
\hline Statement 15 & $-0,07$ & \multirow[b]{2}{*}{-0.0725} \\
\hline Statement 16 & -0.075 & \\
\hline
\end{tabular}

Table 5 represents the average gap score between customer expectation and perception. The charts of details analysis have been attached with the appendices. The average gap score for all the service quality dimensions of Bank $\mathrm{X}$ are showing negative figure where the highest gap scores were for responsiveness. The rest four dimensions show comparatively smaller gap that represents lesser customer dissatisfaction regarding the services.

\section{Scope of SERVQUAL survey}

The concept of measuring the difference between expectations and perceptions in the form of the SERVQUAL gap score proved very useful for assessing levels of service quality. Parasuraman argued that, with minor modification, SERVQUAL can be adapted to any service organization. Information on service quality gaps can help managers diagnose where performance improvement can best be targeted. The largest negative gap, combined with assessment of where expectations are highest, facilitates prioritization of performance improvement. Equally, if gap scores in some aspects of service do turn out to be positive, implying expectations 
are actually not just being met but exceeded, then this allows managers to review whether they may be "oversupplying" this particular feature of the service and whether there is potential for re-deployment of resources into features which are underperforming.

\section{Limitations of SERVQUAL Survey}

- There have been a number of studies that doubt the validity of the 5 dimensions and of the uniform applicability of the method for all service sectors. Despite Parasuraman et al.'s (1988) initial claim that their five service quality dimensions are generic, it is generally agreed that this is not the case, and that the number and definition of the dimensions varies depending on the context. When measuring the quality of accounting firms, Freeman and Dart (1993) conclude that service quality is a seven-dimensional construct. Robinson and Pidd (1998) propose 19 dimensions of service quality in the context of management science projects.

According to Stauss \& Weinlich (1997), a closer look, however, reveals some deficits of attributebased quality measurement (like SERVQUAL). First, the data collected by these methods cannot completely reflect the customer's quality perception. Second, the respondents are forced to aggregate their quality experiences in a problematic way. For example, a customer of a bank asked to evaluate the friendliness of customer contact employees of a bank is forced to tick a single point on a scale even if he/she had contacts with three employees whose behavior and friendliness differed considerably.

Teas (1994) noted that SERVQUAL expectations have been variously defined as desires, wants, what a service provider should possess, normative expectations, ideal standards, desired service, and the level of service a customer hopes to receive. These multiple definitions and corresponding operationalizations of "expectations" in the SERVQUAL literature result in a concept that is loosely defined and open to multiple interpretations (Teas, 1994). Different interpretations of "expectations" include a forecast or prediction, a measure of attribute importance, classic ideal point, and vector attribute (Teas, 1993; Parasuraman et al., 1994b). These various interpretations can result in potentially serious measurement validity problems.

\section{Recommendation For Further Studies/ Researches Regarding Measuring Service Quality:}

- Use of SERVQUAL scale in GAP Analysis model of measuring Service Quality: From the perspective of specific service sector/ organization

- Use of some contemporary models to measure service quality. (Like SERVPERF for Education service)

- Development of a conceptual framework to measure the web-based service quality using the SERVQUAL model.

- Modification of SERVQUAL scale

\section{References:}

[1]. Bexley, James B. (1999), Service quality: an empirical study of expectations versus perceptions in the delivery of financial services in community banks, University of Stirling, December 2005

[2]. Parasuraman, A., Valarie A. Zeithaml, and Leonard L. Berry (1985), “A Conceptual Model of Service Quality in its Implications for Future Research," Journal of Marketing, 49 (Fall), 41-50.

[3]. Zeithaml, Valarie A., Mary Jo Bitner (1990), Services Marketing, New York, Irwin McGraw Hill.

[4]. Parasuraman, A., Zeithaml, V.A., and Berry, L.L. (1988): SERVQUAL: A multiple-item scale for measuring consumer perceptions of service quality. Journal of Retailing, 64, 41-50.

[5]. Peter, J. P., Churchill, G. A., \& Brown, T. J. (1993). Caution in the use of difference scores in consumer research. Journal of Consumer Research, 19(1), 655-662.

[6]. Paul R. Messinger, A Service Quality Audit: An Application of the Gap Analysis Model, (University of Alberta, 1990

[7]. http://www.12manage.com/methods_zeithaml_servqual.html

[8]. http://en.wikipedia.org/wiki/SERVQUAL

[9]. http://findarticles.com/p/articles/mi_qa3713/is_200007/ai_n8893832

[10].

\section{Appendix}

\section{Dear Respondents,}

\section{Customers' Questionnaire (Expectation)}

Any information you provide will be kept strictly confidential. This survey is completely voluntary. Your full participation would greatly help the cause of the study.

Instruction: Please indicate the extent to which the services provided by Bank X should possess the features described by each statement.

Please circle one number for each statement 


\begin{tabular}{|c|c|c|c|c|c|c|c|}
\hline \multirow[b]{2}{*}{$\begin{array}{l}\text { 1. Bank X should maintain all the necessary modem equipment } \\
\text { (Online banking, ATM service, electronic cashing, Intemet banking, credit card } \\
\text { etc.) }\end{array}$} & \multicolumn{7}{|c|}{$\begin{array}{l}\text { Strongly Agref.................................... Strongly } \\
\text { Disagree }\end{array}$} \\
\hline & 1 & 2 & 3 & 4 & 5 & 6 & 7 \\
\hline 2. The employees should be neat-sppearing. & 1 & 2 & 3 & 4 & 5 & 6 & 7 \\
\hline 3. The parmphlets and statements should be cles, attractive and well explained. & 1 & 2 & 3 & 4 & 5 & 6 & 7 \\
\hline 4. The branches should have convenient sitting and waiting arrangements & 1 & 2 & 3 & 4 & 5 & 6 & 7 \\
\hline 5. Bank $X$ should deliver all the services within the promised desdlines & 1 & 2 & 3 & 4 & 5 & 6 & 7 \\
\hline 6. You should feel safe in all your transactions with the bank. & 1 & 2 & 3 & 4 & 5 & 6 & 7 \\
\hline 7. The advertising and promotional messages of Bank $X$ reflect reality. & 1 & 2 & 3 & 4 & 5 & 6 & 7 \\
\hline 8. The bank should maintsing error free records. & 1 & 2 & 3 & 4 & 5 & 6 & 7 \\
\hline 9. The employess should prevent long waiting lines. & 1 & 2 & 3 & 4 & 5 & 6 & 7 \\
\hline $\begin{array}{l}\text { 10. Whenever you face any sort of banking problems, the employeas should help } \\
\text { you solve the problem. }\end{array}$ & 1 & 2 & 3 & 4 & 5 & 6 & 7 \\
\hline 11. The bank should operate a regular and effective complaint handling process & 1 & 2 & 3 & 4 & 5 & 6 & 7 \\
\hline 12. The employess should be quick and efficient in service delivery. & 1 & 2 & 3 & 4 & 5 & 6 & 7 \\
\hline 13. The Branch employess should be continuoualy courteous withyou. & 1 & 2 & 3 & 4 & 5 & 6 & 7 \\
\hline $\begin{array}{l}\text { 14. All the employees should have strong lnowledge to answer your enquiries } \\
\text { about the offerings and their operations. }\end{array}$ & 1 & 2 & 3 & 4 & 5 & 6 & 7 \\
\hline 15. The bank should maintain strang Customer Relationships. & 1 & 2 & 3 & 4 & 5 & 6 & 7 \\
\hline $\begin{array}{l}\text { 16. The bank should always inform you about new and attractive schemes and } \\
\text { always sugeast you on taking the correct dacision. }\end{array}$ & 1 & 2 & 3 & 4 & 5 & 6 & 7 \\
\hline
\end{tabular}

\section{Appendix}

\section{Dear Respondents,}

\section{Customers' Questionnaire (Expectation)}

Any information you provide will be kept strictly confidential. This survey is completely voluntary. Your full participation would greatly help the cause of the study.

Instruction: Please indicate the extent to which you believe Bank X has the features and benefits described by the statements.

\begin{tabular}{|c|c|c|c|c|c|c|c|}
\hline \multirow{2}{*}{$\begin{array}{l}\text { Questionn aire } 2 \text { for response regard ing Customer perception regarding the } \\
\text { service of Bank } \mathrm{X} \\
\text { 1. Bank X hag, all the nacessary modem equipment. } \\
\text { (Online banking, ATM service, electronic cashing, Intemet banking, credit } \\
\text { card etc.) }\end{array}$} & \multicolumn{7}{|c|}{ Strongly Agree........................Strongy Disagree } \\
\hline & 1 & 2 & 3 & 4 & 5 & 6 & 7 \\
\hline 2. The employees are neat-appearing. & 1 & 2 & 3 & 4 & 5 & 6 & 7 \\
\hline 3. The pemphlets and statements are clear, attractive and well explainat & 1 & 2 & 3 & 4 & 5 & 6 & 7 \\
\hline 4. The branches has convenient sitting and waiting arrangements & 1 & 2 & 3 & 4 & 5 & 6 & 7 \\
\hline 5. Bank $X$ delivers all the services within the promised deadlines & 1 & 2 & 3 & 4 & 5 & 6 & 7 \\
\hline 6. You fael safe in all your transactions with the bank. & 1 & 2 & 3 & 4 & 5 & 6 & 7 \\
\hline 7. The advertising and promotional messages of $B$ ank $X$ reflect reality. & 1 & 2 & 3 & 4 & 5 & 6 & 7 \\
\hline 8. The bank maintains error free records. & 1 & 2 & 3 & 4 & 5 & 6 & 7 \\
\hline 9. The employess prevent long waiting limes. & 1 & 2 & 3 & 4 & 5 & 6 & 7 \\
\hline $\begin{array}{l}\text { 10. Whenever you face any sort of banking problems, the employess } \\
\text { belps you solve the problem. }\end{array}$ & 1 & 2 & 3 & 4 & 5 & 6 & 7 \\
\hline 11. The bank operates a regular and effective complaint handling process & 1 & 2 & 3 & 4 & 5 & 6 & 7 \\
\hline 12. The employess are quick and efficient in service delivery. & 1 & 2 & 3 & 4 & 5 & 6 & 7 \\
\hline 13. The Branch employees are continuously courteous withyou. & 1 & 2 & 3 & 4 & 5 & 6 & 7 \\
\hline $\begin{array}{l}\text { 14. All the employes have strong lnowledge to mawer your enquiries } \\
\text { about the offerings and their operations. }\end{array}$ & 1 & 2 & 3 & 4 & 5 & 6 & \\
\hline 15. The bank maintsins strong Customer Relationships. & 1 & 2 & 3 & 4 & 5 & 6 & 7 \\
\hline $\begin{array}{l}\text { 16. The bank always informs you about new and attractive schemes and } \\
\text { always suggest you on talking the correct decision. }\end{array}$ & 1 & 2 & 3 & 4 & 5 & 6 & \\
\hline
\end{tabular}

\section{Appendix}


An Empirical Study of Servqual as a Tool for Service Quality Measurement

Tangibles: Statement 1 to 4 represent the customer feedback regarding Tangibles

\begin{tabular}{|c|c|c|c|c|c|c|c|c|}
\hline \multicolumn{9}{|c|}{ Tangibles: Average Differences between Cousumer Expectatious to Perceptions } \\
\hline Difference & \multicolumn{2}{|c|}{ Statement 1} & \multicolumn{2}{|c|}{ Statement 2} & \multicolumn{2}{|c|}{ Statement 3} & \multicolumn{2}{|c|}{ Statement 4} \\
\hline$D=E-P$ & $\begin{array}{l}\text { No. of } \\
\text { responde } \\
\text { nt }\end{array}$ & 50 & $\begin{array}{c}\text { No. of } \\
\text { responde } \\
\text { nt }\end{array}$ & 96 & $\begin{array}{l}\text { No. of } \\
\text { responde } \\
\text { nt }\end{array}$ & $\%$ & $\begin{array}{l}\text { No. of } \\
\text { responde } \\
\text { nt }\end{array}$ & 56 \\
\hline-6 & 0 & 0 & 0 & ? & 0 & 0 & 0 & 0 \\
\hline-5 & 0 & 0 & 0 & 0 & 0 & 0 & 1 & 25 \\
\hline-4 & 3 & 7.5 & 0 & 0 & 0 & 0 & 2 & 5 \\
\hline-3 & 2 & 5 & 0 & 0 & 0 & 0 & 7 & 17.5 \\
\hline-2 & 9 & 22.5 & 0 & 0 & 3 & 7.5 & 12 & 30 \\
\hline-1 & 15 & 37.5 & 7 & 17.5 & 9 & 22.5 & 8 & 20 \\
\hline 0 & 8 & 20 & 18 & 45 & 19 & 475 & 5 & 125 \\
\hline 1 & 3 & 75 & 10 & 25 & 5 & 12.5 & 5 & 12.5 \\
\hline 2 & 0 & 0 & 5 & 125 & 4 & 10 & 0 & 0 \\
\hline 3 & 0 & 0 & 0 & 0 & 0 & 0 & 0 & 0 \\
\hline 4 & 0 & 0 & 0 & 0 & 0 & 0 & 0 & 0 \\
\hline 5 & 0 & 0 & 0 & 0 & 0 & 0 & 0 & 0 \\
\hline \multirow[t]{2}{*}{6.} & 0 & 0 & 0 & 0 & 0 & 0 & 0 & 0 \\
\hline & \multicolumn{2}{|c|}{ Statement 1} & \multicolumn{2}{|c|}{ Statement 2} & \multicolumn{2}{|c|}{ Statement 3} & \multicolumn{2}{|c|}{ Statement 4} \\
\hline $\begin{array}{c}\text { Mean } \\
\text { Difference }\end{array}$ & \multicolumn{2}{|c|}{-1.2} & \multicolumn{2}{|c|}{0.325} & \multicolumn{2}{|c|}{-0.05} & \multicolumn{2}{|c|}{-1525} \\
\hline
\end{tabular}

Reliability: Statement 5 to 8 represent the customer feedback regarding Reliability

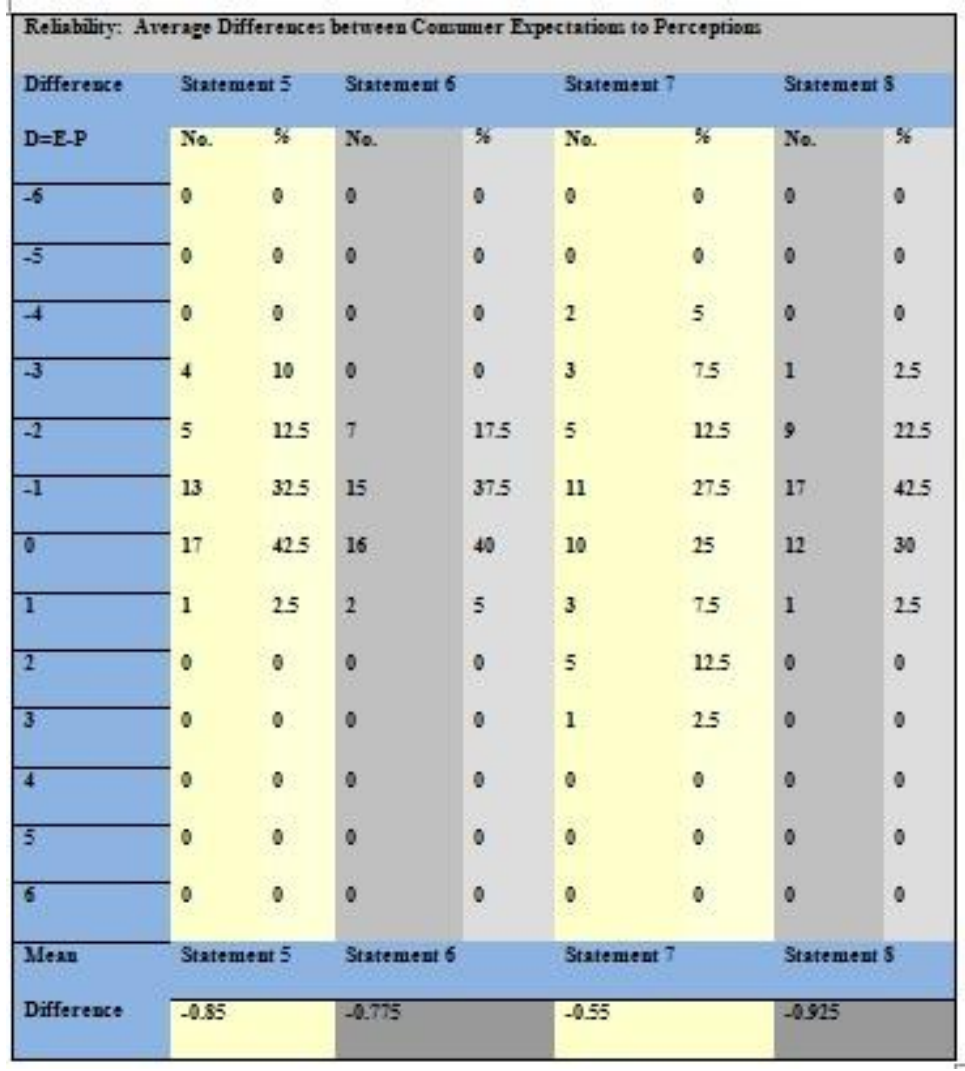

Responsiveness: Statement 9 to 11 represent the customer feedback regarding Responsiveness 
An Empirical Study of Servqual as a Tool for Service Quality Measurement

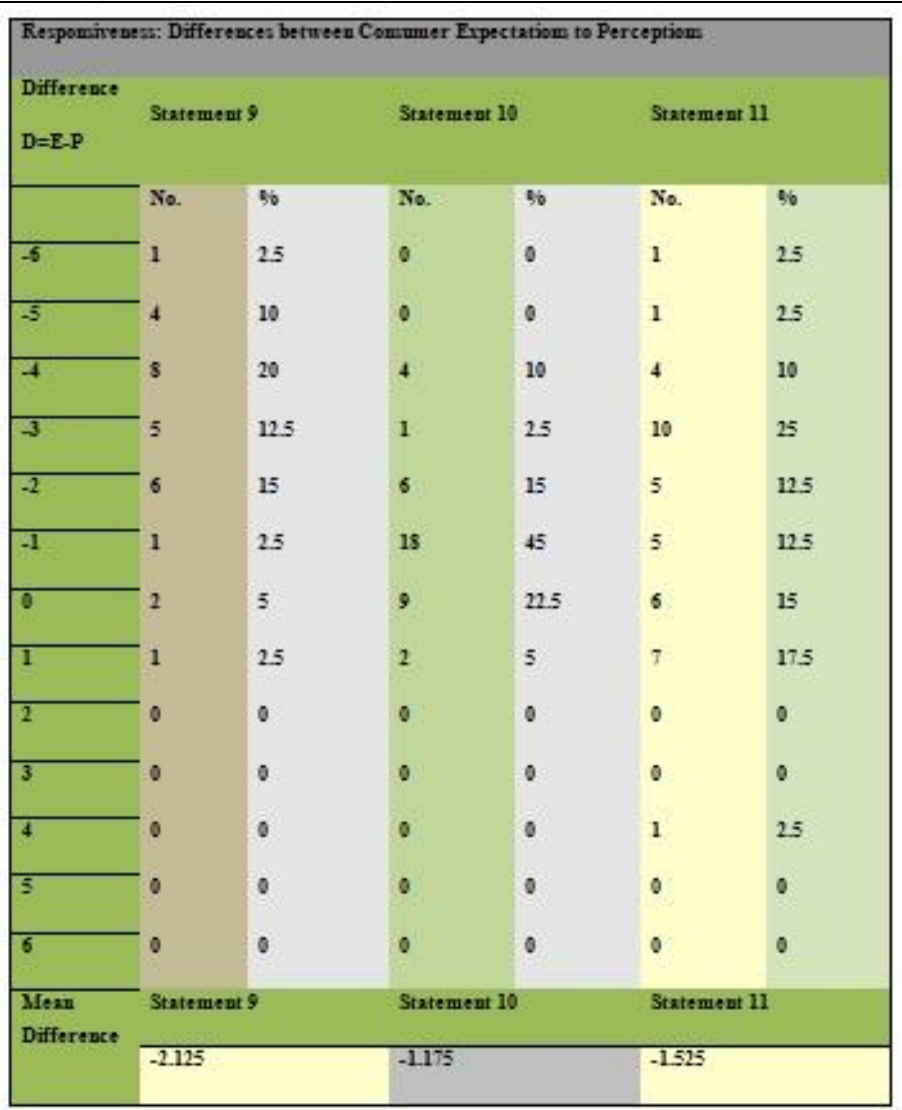

Appendix

Assurance: Statement 12 to 14 represent the customer feedback regarding Assurance

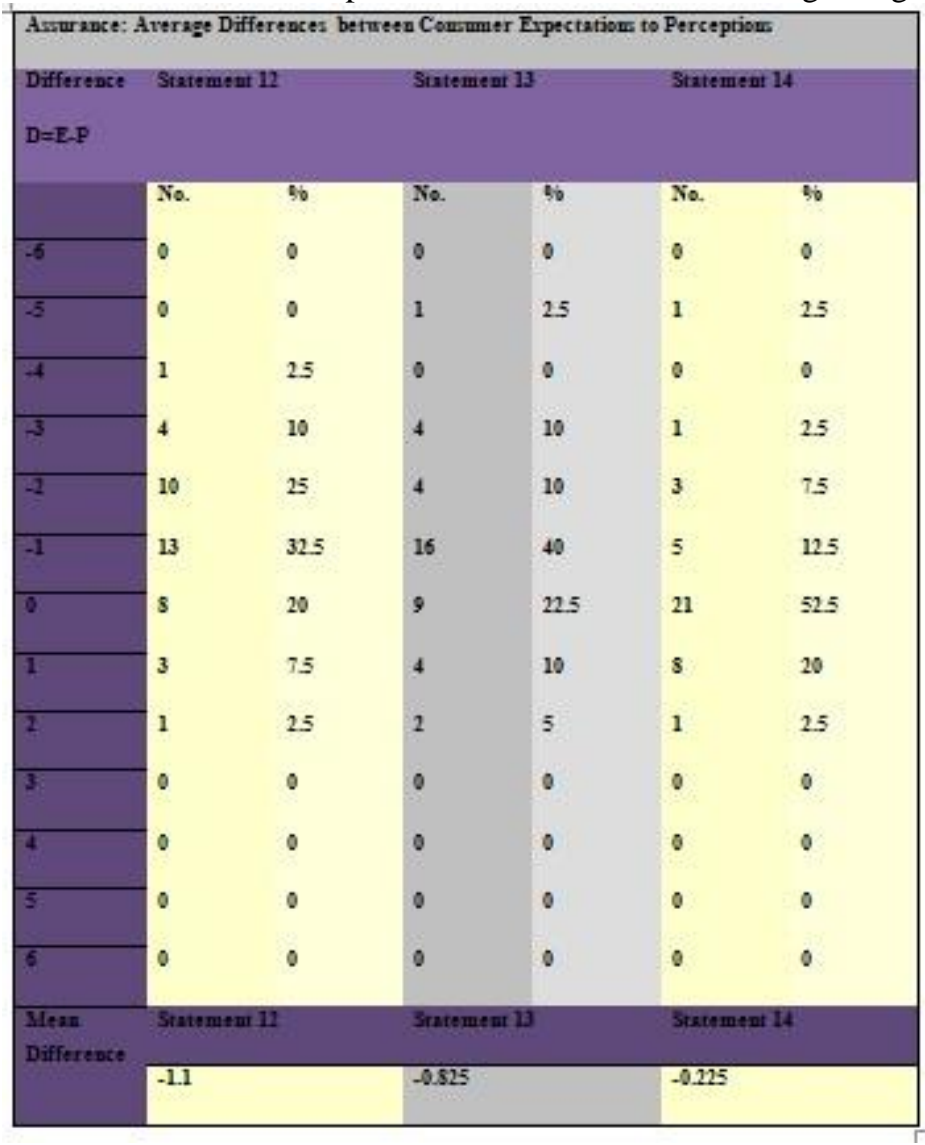



Appendix

Empathy:

Statement 15 and 16 represent the customer feedback regarding Empathy

\begin{tabular}{|c|c|c|c|c|}
\hline \multicolumn{5}{|c|}{ Empathy: Average Differences between Consumer Expectations to Perception } \\
\hline \multirow{2}{*}{$\begin{array}{l}\text { Difference } \\
D=E-P\end{array}$} & \multicolumn{2}{|c|}{ Statement 15} & \multicolumn{2}{|c|}{ Statement 16} \\
\hline & No & $\%$ & No & $\%$ \\
\hline-6 & $\mathbf{0}$ & $\mathbf{0}$ & $\mathbf{0}$ & $\mathbf{0}$ \\
\hline-5 & $\mathbf{0}$ & $\mathbf{0}$ & $\mathbf{0}$ & $\mathbf{0}$ \\
\hline-4 & $\mathbf{0}$ & $\mathbf{0}$ & $\mathbf{0}$ & $\mathbf{0}$ \\
\hline-3 & 2 & 5 & $\mathbf{0}$ & $\mathbf{0}$ \\
\hline-2 & 10 & 25 & 5 & 12.5 \\
\hline-1 & 9 & 22.5 & 8 & 20 \\
\hline $\mathbf{0}$ & 13 & 32.5 & 16 & 40 \\
\hline 1 & 5 & 12.5 & 8 & 20 \\
\hline 2 & 1 & 2.5 & 2 & 5 \\
\hline 3 & $\mathbf{0}$ & $\mathbf{0}$ & 1 & 2.5 \\
\hline 4 & $\mathbf{0}$ & $\mathbf{0}$ & $\mathbf{0}$ & $\mathbf{0}$ \\
\hline 5 & $\mathbf{0}$ & $\mathbf{0}$ & $\mathbf{0}$ & $\mathbf{0}$ \\
\hline 6 & $\mathbf{0}$ & $\mathbf{0}$ & $\mathbf{0}$ & $\mathbf{0}$ \\
\hline \multirow{2}{*}{$\begin{array}{l}\text { Mean } \\
\text { Difference }\end{array}$} & \multicolumn{2}{|c|}{ Statement 15} & \multicolumn{2}{|c|}{ Statement 16} \\
\hline & \multicolumn{2}{|c|}{-0.07} & \multicolumn{2}{|c|}{-0.075} \\
\hline
\end{tabular}

